\title{
Case study: a brownfield site in suburban New York
}

\author{
Y. Hashimoto ${ }^{1}$, J. Brooks ${ }^{2}$, E. Conti ${ }^{1}$, D. Averill ${ }^{1}$, M. Beck ${ }^{1}$ \\ \& D. Behnken ${ }^{1}$ \\ ${ }^{1}$ Geomatrix Consultants, Inc., Oakland, California, USA \\ ${ }^{2}$ Phillips Nizer LLP, New York, New York, USA
}

\begin{abstract}
A fleet fueling facility reported a gasoline release in 1987 when impacted soils were encountered during the removal of two underground storage tanks. The subsequent remedial investigation indicated that separate-phase and dissolved-phase gasoline had migrated onto an adjacent property, consisting of a childcare facility and a wetland. Geomatrix utilized real-time-data collection methods, including the membrane interface probe, soil vapor screening, and physical analysis of soil in the field, to expedite delineation of the residual separate-phase product and impacted soil. The current property owner applied for entry into the New York State Brownfield Cleanup Program, which provides a multi-track cleanup approach to achieve closure based on land use and site-specific conditions. The program offers technical assistance grants and provides incentives to expedite cleanup, including limitations on liability and tax credits of $10-22 \%$. Excavation was selected for removal of the residual product in the soil. Concurrent dewatering operations removed approximately 620,000 gallons of impacted groundwater. Clean backfill mixed with an oxygen release compound $(\mathrm{ORC} \cap)$ was placed in the excavation at and below the water table to increase oxygen availability in the groundwater, thereby enhancing aerobic degradation of dissolved petroleum hydrocarbons. The work was implemented on an expedited schedule, with activities commencing during the winter holiday to minimize impact to the childcare facility's operation.
\end{abstract}

Keywords: brownfield, petroleum, excavation, expedited site characterization, membrane interface probe, mobile laboratory, soil vapor, tax credits. 


\section{Introduction}

In the United States, the remediation and redevelopment of most brownfield sites are regulated by state (as distinct from federal) programs. The New York State Brownfield Cleanup Program (BCP), enacted in October 2003, provides legal and financial incentives to remediate and redevelop properties that are, or are perceived to be, contaminated. Most meaningful among the incentives are relief from legal liability to the state of New York, and credits against New York state income tax liability. The credits - calculated as a percentage of not only the cost of remediation but also the hard cost of redevelopment-constitute the most lucrative financial incentive of any brownfield program in the United States. The base percentage for individuals and similarly situated taxpayers is ten percent $(10 \%)$; for non-pass-through corporations and similarly situated taxpayers, the base percentage is twelve percent (12\%) (NYSDEC [1]). An additional two percent $(2 \%)$ is added if the remediation plan achieves the most stringent standard ("unrestricted use"). If at least half of the subject property is located in an Environmental Zone (a census tract with either high poverty or high unemployment), an additional eight percent (8\%) is added. Furthermore, to the extent that the credits exceed the taxpayer's New York State income tax liability, the balance is paid to the taxpayer as a refund (NYSDEC [1]).

The $\mathrm{BCP}$ requires that both a site and an applicant be eligible. A site is ineligible if it is already listed on the National Priority List or on the New York State Registry of Inactive Hazardous Waste Sites, or if the site is already the subject of an enforcement action under federal or state environmental law. An applicant is ineligible if, among other things, they have committed a felony in New York State or owe money to the New York State Oil Spill Fund (NYSDEC [1]).

In an effort to encourage the remediation and redevelopment of as many brownfield sites as possible, the BCP permits even "responsible parties"- those who caused or contributed to the contamination at a site-to apply. The BCP characterizes such parties as "participants," while those who are unconnected to the contamination are "volunteers."

Currently, both participants and volunteers are eligible for the same set of legal and financial incentives (amendments to the BCP recently proposed by New York Governor Spitzer would significantly reduce the tax credits available to participants). The BCP, however, does treat them differently in one very important respect: while participants are obligated to chase and clean up contamination emigrating from the subject site, volunteers are obligated to remediate only on-site contamination (NYSDEC [1]).

The BCP requires an applicant to involve the public and provide a citizen participation plan (NYSDEC [1]). The minimal requirement for involvement includes public notification via "fact sheets" describing the major issues of public concern, the site cleanup progress, and draft documents available for public review. Draft documents required of the applicant by the state are made available at a document repository for 30-45-days for public comment. 
Interim remedial measures are encouraged by the state and are evaluated based on time-critical (emergency response action) or non-time-critical site cleanup needs. Time-critical remediations are expedited by waiving the public document review and extensive remedial investigations. Non-time-critical interim remedial measures are more discretionary and approval is similar to other remediations (requiring citizen participation). The state waives other processes to expedite remediation under the $\mathrm{BCP}$, including the procedure for obtaining approved work permits. An applicant is required to submit all required permit applications for investigation and remediation, but an applicant may perform work prior to receipt of permit approval.

The site closure process is driven by soil concentrations. Soil cleanup levels are risk-based and multi-track, contingent upon land use. The applicant selects the appropriate cleanup track target-unrestricted or restricted (residential, commercial, or industrial) - for the site. If the applicant is a participant, off-site investigation and subsequent cleanup is required; however, off-site properties are not entered into a specific cleanup track. Each of the cleanup tracks addresses groundwater cleanup goals, easements, or restrictions. Soil vapor evaluations, such as subslab vapor sampling, are commonly incorporated into the site investigation process to assuage perceived risks from soil and groundwater contamination.

\subsection{Site setting}

The 2.7-acre site is currently an active fleet car rental facility located in suburban New York within a commercial/residential area. Approximately 14,000 square feet of the eastern portion of the property are occupied by an office and maintenance building (fig. 1). The remainder of the site property is used primarily for vehicle storage and is paved with asphalt and concrete, with the exception of some landscaped traffic berms. The topography of the site slopes gently downward to the south and southeast. Neighboring properties include commercial facilities to the north, east and west, and a childcare facility and wetland to the south.

The geology of the site and the adjacent property consists of silty sand overlying an intermittent peat layer and an intermittent gravel layer, with an underlying layer of silt and clay. Groundwater depths range from 4.5 to 10 feet below ground surface (bgs) at the site and between 1 to 3 feet bgs at the adjacent property to the south. Shallow groundwater flow direction has generally ranged from west to south beneath the site and from southwest to southeast beneath the adjacent property.

\subsection{Background}

A gasoline release at the site, a car rental facility, was reported to the New York State Department of Environmental Conservation (NYSDEC) when impacted soils were encountered during the removal of two gasoline underground storage tanks (USTs), which had been in use for approximately 21 years. Groundwater monitoring wells were installed and water samples were collected from the wells 
for analysis. Analytical data for groundwater samples collected from the monitoring wells indicated that the release had extended onto the adjacent property to the south, which includes a childcare facility and a wetland (fig. 1).

The monitoring wells were sampled again approximately six years after the prior groundwater sampling event, and the analytical results were similar to previous events. However, floating free product (gasoline) was found in one monitoring well near the location of the former USTs. Floating free product, other than a sheen, had not previously been reported at the site.

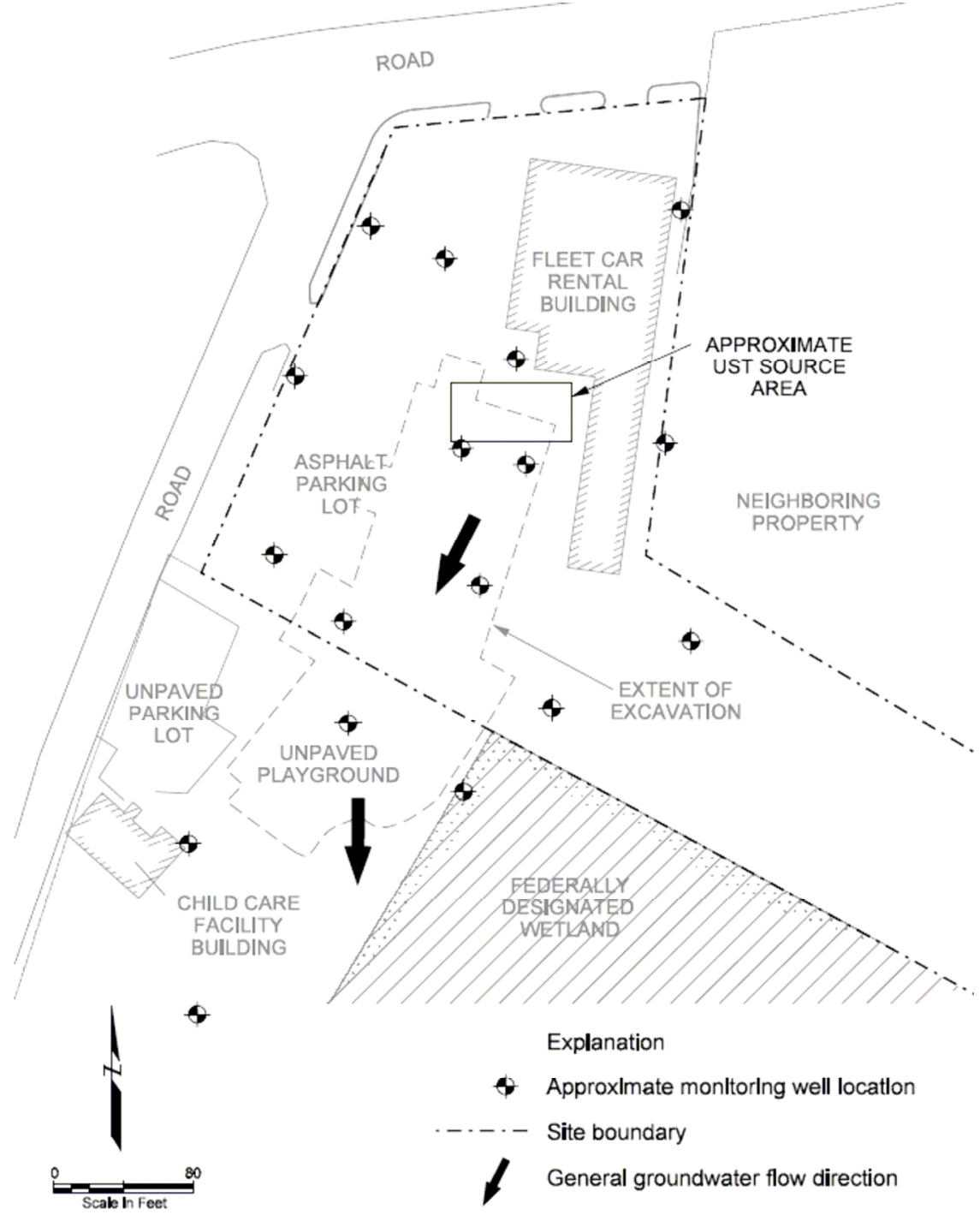

Figure 1: $\quad$ Site map. 
Upon discovery of the floating free product, the status of the site was discussed with the NYSDEC, who concurred that the contamination was related to the release found during the UST excavation. An interim remedial measurehigh-vacuum extraction - was conducted to remove the free product. Further investigations were implemented, including soil sampling near the well with floating free product, and depth-discrete groundwater sampling on the adjacent property to the south, but no floating free product was observed. Dissolved petroleum constituents were present in groundwater on the adjacent property to the south, but did not extend underneath the childcare facility building. The site property owner applied for entry to the Brownfield Cleanup Program as a volunteer and was accepted only as a participant; a Brownfield Site Cleanup Agreement was executed in 2005.

During a September 27, 2005, meeting, the NYSDEC and property owner agreed to implement a further interim remedial measure consisting of residual source removal through excavation of petroleum-impacted soils using conventional earthmoving equipment. Geomatrix developed and submitted an interim remedial measure work plan, received approval, and implemented the work in December 2005.

\section{Summary of remedial investigations}

Remedial investigation work, including the use of expedited site characterization techniques, defined the nature of contamination and identified the source and extent of petroleum hydrocarbons in soil and groundwater. The extent of residual hydrocarbons in soil was estimated within three days by advancing 22 borings using direct-push drilling rods equipped with a soil conductivity (SC) probe and a membrane interface probe (MIP). The SC probe provides soil lithology and the MIP provides volatile organic chemical data. The MIP contains a sensor that continuously logs volatile organic compounds that diffuse through a heated semipermeable membrane. The volatile organic compounds are brought to the surface through tubing that is connected to a detector for immediate analysis. The MIP served to qualitatively define areas with higher concentrations of petroleum constituents, both laterally and vertically. A calibration was made between the MIP logs and four companion soil borings advanced by direct push and visually logged and sampled. The extent of petroleum contamination was quantified in the visually logged soil borings with headspace readings from a portable photoionization detector (PID) and analysis of select soil samples by an off-site laboratory.

The extent of contamination in soil and groundwater was delineated and the target excavation area was defined based in part on the SC probe/MIP soil boring investigation. After defining the target excavation area, limited additional investigations were conducted to provide design information for the excavation, including advancing geotechnical borings, and to investigate potential preferential pathways, including a geophysical survey and drilling with an air knife and vacuum. Geophysical techniques utilized at the site included induced electromagnetic field and ground penetrating radar. 
Soil vapor investigations were conducted prior to and following the excavation at the downgradient, off-site extent of the delineated groundwater plume. The purpose of the soil vapor investigations was to assess the risks associated with the soil vapor pathway at the downgradient extent of the groundwater plume, and to determine the effectiveness of the excavation in mitigating soil vapor migration. Because of the sensitive receptors (child care facility) downgradient of the site, subslab sampling was conducted at the child care facility building following excavation and restoration activities, as directed by the New York State Department of Health (NYSDOH). The NYSDOH works in tandem with the NYSDEC and is the lead agency for review for soil vapor investigations.

\section{Interim remedial measure excavation}

Regulatory requirements for approval of the interim remedial measure excavation were a hybrid of time critical and non-time critical. An interim remedial measure work plan was submitted (non-time-critical requirement), but public review was waived (time-critical waiver). The public review waiver facilitated implementation of the interim remedial measure excavation on an expedited schedule to accommodate the childcare facility's winter holiday schedule. The interim remedial measure work plan was approved within a month of submittal and excavation began three weeks later. Within those three weeks preparatory activities were conducted, including contractor selection, permit application submittal, utility clearance, survey control, site facility building natural gas service pipeline realignment, existing feature removal (i.e., playground equipment, trees, and other foliage), and site security setup (fencing).

The interim remedial measure excavation was conducted in two stages: onsite and off-site. Each stage included soil excavation, stockpiling, and loading; confirmation soil sample collection and analysis; excavation groundwater extraction, treatment, and sampling; monitoring well destruction; backfilling and paving; and excavated soil characterization and disposal. Because of the childcare facility's operating schedule, the selected approach was to excavate off site prior to excavating the on-site source area. A dewatering trench and clean buffer zone was maintained between the on- and off-site excavation areas to minimize the potential for contaminated groundwater to migrate from the site to the recently backfilled off-site area before all excavation activities could be completed.

\subsection{Soil excavation}

The anticipated excavation extent was delineated based on the expedited field screening and soil sampling described in Section 2. The actual horizontal and vertical extents of excavation were refined during implementation based on the results of soil confirmation samples analyzed by an on-site mobile laboratory. Final analytical confirmation was obtained using an off-site laboratory certified by the New York State Environmental Laboratory Accreditation Program 
(ELAP) because the state will not accept analytical results from laboratories, including the mobile laboratory, without ELAP certification.

Soil sample analytical results were compared to recommended soil cleanup objectives known as TAGM 4046 (Technical and Administrative Guidance Memorandum 4046) during the excavation work, and in most areas the cleanup objectives were obtained. After the excavation activities, however, different track-specific soil cleanup levels (Subsection 375-6.8 Soil Cleanup Objective Tables) applicable to this site were released by the state (NYSDEC [2]). The site soil confirmation samples were compared to the unrestricted soil cleanup objectives, rather than restricted soil cleanup objectives for residential, commercial, or industrial land use. The post-excavation unrestricted cleanup objectives were similar to or more stringent than those applied during excavation.

The confirmation soil sample results were below the recommended unrestricted soil cleanup levels, with a few exceptions. These exceptions were in areas where further excavation was not feasible. The off-site excavation was not extended east into the federally designated wetlands, nor was it extended vertically beyond 12 to 14 feet bgs in the saturated silt and clay. On-site excavation could not be extended east of the shoring, which was installed near the site building to protect foundation integrity. To mitigate the potential impact to groundwater of these exceedances, Oxygen Release Compound, or ORC ${ }$, a proprietary material produced by Regenesis, Inc., was added to the backfill material in the excavation to enhance biodegradation of petroleum constituents in groundwater.

\subsection{Groundwater treatment}

Dewatering was performed to facilitate the soil excavation, confirmation soil sampling, backfilling and compaction, and to maximize mass removal of petroleum hydrocarbons during excavation activities. The extracted groundwater was treated by an on-site treatment system and discharged to the sanitary sewer. Approximately 620,000 gallons of groundwater were extracted, treated, and discharged. Geomatrix submitted a wastewater discharge permit application to the town and, as allowed by the BCP, commenced work without receiving an actual permit. Geomatrix complied with provisions that would typically be included in a permit and provided regular updates to the town on the status of treated water discharges to the sanitary sewer

\section{Restoration}

Restoration of on- and off-site properties resulted in property improvements eligible for tax credits. The off-site restoration activities included grading, installing new property boundary fencing, placing topsoil (for planting vegetation), and installing new playground equipment and other amenities. Onsite property improvements included repaving the entire parking area (including the area of excavation) and replacing groundwater monitoring wells removed 
during the excavation activities. The effectiveness of the interim remedial measure excavation is being assessed with ongoing groundwater monitoring in on- and off-site wells.

\section{Summary and current status}

The site owner entered the BCP as a participant and shortly thereafter implemented an interim remedial measure excavation. The interim remedial measure excavation is intended to serve as the final remedy because it achieves the remedial goal established for the site (NYSDEC [1]). Site closure is obtained by the issuance of a "Certificate of Completion," thereby releasing the site owner of liability to the state for hazardous waste emanating from the site, and triggering eligibility for tax credits. A Certificate of Completion is issued based on determinations that remediation requirements have been achieved or will be achieved under an approved work plan and upon review and approval of a Final Engineering Report (NYSDEC [1]). These two documents will be submitted to the state in 2008.

Groundwater monitoring is the only ongoing activity following completion of restoration. Groundwater monitoring was conducted quarterly for six quarters and then was reduced to annually (every fifth quarter, to account for seasonal variations). Because dissolved petroleum constituents are present in groundwater, the state may impose a temporary environmental easement on the site until five consecutive quarters of monitoring provide analytical results that groundwater is within water quality objectives. The environmental easement serves to restrict groundwater use until natural attenuation achieves dissolved petroleum concentrations satisfactory to the state. The easement will not affect issuance of the Certificate of Completion.

Approximately \$5 million U.S. dollars in hard and soft remediation costs have been incurred. Up to 14 percent $(14 \%)$, or $\$ 700,000$, will be available for tax credits upon issuance of a Certificate of Completion for an unrestricted closure track. The site is not in an Environmental Zone and is thus ineligible for additional tax credits. Those costs incurred prior to execution of the BCP agreement between the site owner and the state are not eligible for tax credits. However, the substantial available tax credits make the BCP a worthwhile cleanup pathway for this and other eligible sites.

The BCP is relatively new (2003) and continues to evolve. Specifically during this site's participation in the BCP, requirements for reports, fact sheets, and soil cleanup levels have deviated from the initial state requests and requirements. This is not unexpected, considering the numerous regulatory documents governing the BCP (NYSDEC [1-3]); participation from other agencies (NYSDOH involvement); and numerous public and regulatory steps. The BCP will become more refined as more sites, like this one, enter and complete the BCP process. Fortunately, sufficient incentives are provided to encourage participation in the program and to stimulate the cleanup and reuse of brownfields. 


\section{References}

[1] New York State Department of Environmental Conservation (NYSDEC), Draft Brownfield Cleanup Program Guide, May 12, 2004.

[2] NYSDEC, 6 NYCRR Part 375 Environmental Remediation Program, December 14, 2006.

[3] NYSDEC, Draft DER-10 Technical Guidance for Site Investigation and Remediation, December 25, 2002. 